\title{
Kapitalismi maailmanekologiana
}

\section{Tero Toivanen}

Jason W. Moore (2015) Capitalism in the Web of Life. Ecology and the Accumulation of Capital. Lontoo: Verso.

Binghamtonin yliopiston ympäristöhistorian ja poliittisen talouden tutkija Jason W. Moore tunnetaan historiallisesti orientoituneen sosiologian piirissä laajoista kapitalismin ympäristöhistoriaa käsittelevistä artikkeleistaan. Niissä hän hyödyntää erityisesti Fernand Braudelin, Immanuel Wallersteinin ja Giovanni Arrighin maailmanhistoriallista analyysivälineistöä. Mooren tutkimukset kiinnittyvät teoreettisesti marxilaiseen ekologiaan, minkä lisäksi hän ammentaa esimerkiksi poliittisen ekologian ja feministisen teorian perinteistä. Hänen uusin teoksensa Capitalism in the Web of Life kehittää teoreettis-metodologista analyysivälineistöä, jota kutsutaan maailmanekologiaksi (world-ecolog $\gamma)$. Moore tähdentää, että maailmanekologia ei ole "valmis" teoria, vaan vallan, pääoman ja luonnon kehitystä historiallisesti yhtyeenkietoutuneina analysoiva perspektiivi.

Capitalism in the Web of Life jakaantuu neljään osaan. Ensimmäisessä osassa Moore esittää maailmanekologian filosofiset lähtökohdat kritisoimalla modernille ajattelulle tyypillistä karteosilaista dualismia eli erottelua luonnon ja yhteiskunnan välillä. Tämän jaon ylittämiseksi ja "jälkikartesiolaisen" kapitalismikritiikin kehittämiseksi Moore ehdottaa luonnon haltuunoton strategioiden sisällyttämistä Marxin arvolakiin. Toisessa osassa teoretisoidaan, kuinka kapitalismin tapa ottaa haltuun "halpaa luontoa" (cheap nature) johtaa tendenssimäisesti "ekologisen lisäarvon" laskuun ja lopulta järjestelmän uusintamiskriisiin. Kolmannessa osassa Moore tarkastelee kapitalistisen maailmanekologian syntyä ja kehitystä "pitkällä 1500luvulla" (1450-1648) ${ }^{1}$.Neljännessä osassa Moore tarkastelee kahden "halvan luonnon" eli ihmistyön (palkkatyön ja uusintavan työn) ja ruoantuotannon historiallista merkitystä kapitalismin kehitykselle, kriisiytymiselle ja uusille nousukausille. 
Ilmastonmuutos ja muut ekologiset kriisit ovat vaikuttaneet siihen, että useissa ihmistieteissä on viime vuosina etsitty metodologista ja teoreettista ulospääsyä yhteiskunnan ja luonnon välisestä ongelmallisesta erottelusta. Mooren mukaan jaottelu ei ole vain modernin tieteen keskeinen ongelma vaan kapitalistisen maailmanjärjestyksen muotoutumisen edellytys: luonnon ymmärtäminen yhteiskunnan "ulkopuolisena" on mahdollistanut sen syvenevän riiston viimeisen viidensadan vuoden aikana. Mooren mielestä myös viime vuosikymmenien edistyksellinen ympäristöajattelu kärsii kartesiolaisesta erottelusta. Tarkastelun lähtökohtana vihreässä ajattelussa on, kuinka ihminen riistää luontoa ja heikentää sen tilaa. Tällöin päädytään helposti katastrofikuvastoon ja romahdusajatteluun. Mooren mukaan vaihtoehto ei ala "ihmisestä" eikä "luonnosta", vaan suhteista, tarkemmin määriteltynä "kaksoissisäisyydestä" (double internality), eli ihmisyydestä luonnossa ja luonnosta ihmisyydessä. Maailmanekologiassa siis halutaan analysoida dialektista suhdetta, jossa kapitalismi vaikuttaa luontoon ja luonto kapitalismiin. On selvää, että kyseessä on tehtävä, jonka filosofinen julkilausuminen on helpompaa kuin sen metodologinen noudattaminen tutkimustyössä.

Mooren käsitteellinen ehdotus luonnon ja yhteiskunnan välisen jaottelun ylittämiseksi ja "kaksoissisäisyyden" hahmottamiseksi perustuu kreikan "suotuisaa paikkaa" tarkoittavaan sanaan oikeios. Merkittävä osa ympäristöajattelusta kysyy kysymyksiä, kuten: kuinka ihmiset häiritsevät ekosysteemejä ja aiheuttavat ympäristötuhoja? Oikeioksen näkökulmasta päädytään sen sijaan erilaisiin lähtökohtiin: kuinka ihmisyys kietoutuu yhteen luonnon kanssa elämän verkossa? Kuinka ihmiset ovat mobilisoineet luonnon tuottamaan luodakseen historiallisia valta-asetelmia ja vaurautta? Sen sijaan, että kysyttäisiin, mitä kapitalismi aiheuttaa luonnolle, oikeios johdattaa kysymään, kuinka luonto työskentelee kapitalismille.

Capitalism in the Web of Life pyrkii muuntamaan "kaksoissisäisyyden" filosofiset lähtökohdat kapitalismikriittiseksi metodiksi. Moore pyrkiikin sisällyttämään luonnon paremmin marxilaiseen arvoteoreettiseen keskusteluun. Hän muistuttaa useampaan otteeseen, ettei hänen ajatuksenaan ole suinkaan luopua marxilaiselle arvoteorialle keskeisestä yhteiskunnallisesti välttämättömän työn ajatuksesta, vaan tarkastella sitä, kuinka tämä historiallinen työn muoto on ylipäätänsä mahdollinen. Riiston (exploitation) ja haltuunoton (appropriation) käsitteiden välinen yhteys on tässä keskeinen. Riistämällä abtraktia yhteiskunnallista työtä kapitalismissa muodostetaan 
arvoa, mutta haltuunottamalla tavaratuotannon ulkopuolista halpaa luontoa joko ilmaiseksi tai hyvin edullisesti luodaan edellytykset kapitalismille ominaisille palkkatyön riistämiselle, tavaratuotannolle ja pääoman kasautumiselle. Tämä halpa luonto koostuu Mooren käsittein "neljästä halvasta" (four cheaps), joita ovat ihmistyö, energia, ruoka ja raaka-aineet.

Kapitalismi ei ole vain järjestelmä, jonka on jatkuvasti mullistettava tavaratuotantoaan, vaan sen on myös jatkuvasti etsittävä ja tuotettava halpaa ihmistyötä, energiaa, ruokaa ja raaka-aineita. Kaikki merkittävät historialliset pääoman kasautumisen ajanjaksot ovat alkaneet "neljän halvan" saatavuuden ja tuotannon vallankumouksella. Esimerkiksi Englannin teollinen vallankumous edellytti sekä halvan työn (työvoiman, uusintavan työn ja orjatyön) saatavuutta, maatalouden vallankumousta, fossiilienergian teollista valjastamista ja ennen näkemätöntä luonnonresurssien maailmanlaajuista kulutusta. Kun halpojen resurssien saanti lopulta tyrehtyy, siis pääoman hyödyntämä "ekologinen lisäarvo" laskee, tuotantokustannukset nousevat ja pääoman kasautuminen hidastuu. Tämä taas pakottaa paitsi resurssien käyttöä tehostaviin teknisiin innovaatioihin, myös uusien maailmantalouden raja-alueiden (frontier) avaamiseen ja kapitalismin maantieteelliseen laajenemiseen. Historiallisten raja-alueiden avaamisessa ei ole kyse pelkästään materiaalisesta valloituksesta, vaan myös uudenlaisista tavoista hahmottaa maailma ja luonto. Esimerkiksi ajan mittaamisen, navigoinnin, kartografian ja kasvitieteen kehityksen vallankumoukset ovat kaikki materialisoituvia symbolisia välineitä, joilla on rakennettu länsimaiden hallitsemaa maailmanekologiaa 1400-luvun puolivälistä alkaen.

Moore painottaa, että nykyiset ympäristöongelmamme eivät palaudu teolliseen vallankumoukseen vaan maailmanekologiseen kehitykseen “pitkällä 1500-luvulla”. Niinpä esimerkiksi nopeasti popularisoituva antroposeeni-argumentti ${ }^{2}$ ja fossiilitalouden ympäristöhaittoja korostavat tutkimussuuntaukset keskittyvät Mooren mukaan liiaksi höyrykoneeseen ja fossiilienergiaan. Huomion kiinnittäminen teollista vallankumousta edeltäville vuosisadoille auttaa näkemään, kuinka vallan, pääoman kasautumisen ja luonnon ennen näkemättömän intensiivinen yhtyeenkytkeytyminen loivat edellytykset myöhemmän fossiilikapitalismin ekologiselle turmiollisuudelle. Aikakautta havainnollistavana ympäristöhistoriallisena esimerkkinä mainittakoon, että kun keskiajan Pohjois-Ranskassa kesti 200 vuotta kaataa 12000 hehtaaria metsää, niin kolonialisoidussa Etelä-Amerikassa 
1650-luvulla sama alue hakattiin yhdessä ainoassa vuodessa. Kapitalismin ympäristöhistoriaa ei voi siis ymmärtää ilman maailmanekologian kehittymistä järjestelmänä. Moore ehdottaakin, että antroposeenin, siis ihmisen aikakauden sijaan puhuttaisiin pääoman aikakaudesta, kapitaloseenista.

Maailmanekologia ei ole vain menneen ajan tutkimusta vaan myös nykyisyyden "historiallistamista". Kirjan lopuksi Moore tarkastelee kattavasti "halvan luonnon" maailmanekologista kehitystä viime vuosikymmeninä. Aikaisemmissa historiallisissa järjestelmäkriiseissä kapitalismi on kyennyt ratkaisemaan "neljän halvan" saatavuusongelmat tieteellis-teknisin tai poliittisin keinoin. Moore kuitenkin väittää, että uusliberalismin aikana kapitalismi ei näyttäisi kykenevän tuottamaan enää vallankumousta näillä alueilla. Historiallinen umpikuja johtuu hänen mukaansa useista tekijöistä. Vaikka palkat ovat polkeneet paikallaan tai alentuneet lännessä, globaalisti työn hinta on kohonnut. Fossiilienergian viime aikojen hinnan laskusta huolimatta fossiilivarannot ovat ehtymässä ja niiden tuottamisesta tulee yhä kalliimpaa. Geenimanipulaatiopyrkimyksistä huolimatta maatalouden tuottavuus on heikentymässä esimerkiksi lannoitusongelmien vuoksi. Lisäksi nykymuotoisen teollisuuden keskeiset raaka-aineet niukkenevat. Mooren mukaan kapitalismin on kyettävä ratkaisemaan nämä ongelmat nopeasti, tai edessä on joko entistä vakavampi maailmanekologinen kriisi tai välttämättömyys luoda kapitalismille vaihtoehtoinen järjestelmä.

Mooren työstä kuvastuu laaja historiallinen lukeneisuus. Kirja on pullollaan kiinnostavia historiallisia näkökulmia, joista vain keskeisempien esittely on ollut tässä mahdollista. Vahvimmillaan Capitalism in the Web of Life on kapitalismin syntyä käsittelevissä jaksoissa. Mooren aikaisemmista tutkimuksista ponnistavaa konkreettista kapitalismin ympäristöhistoriaa olisi kuitenkin voinut olla kirjassa mukana enemmänkin. Nyt sitä on liitetty mukaan jopa turhan luettelomaisesti esimerkiksi tiivistämällä "pitkän 1500-luvun" maailmanekologinen kehitys muutaman sivun luetteloksi. Marxilaisen arvoteoreettisen keskustelun ekologinen avaus on joka tapauksessa tervetullutta ja avaa varmasti jatkokeskustelua.

Moitittavaakin kirjasta löytyy. Rakentaessaan filosofisia ja teoreettisia lähtökohtia maailmanekologialle Moore ajautuu toisinaan toistamaan eroaan aikaisempaan ympäristöajatteluun varsin fraasinomaisesti, mikä tekee erityisesti johdantoa seuraavan kahden ensimmäisen osan lukemisesta paikoitellen varsin turhauttavaa. Pitkän johdannon tiivistäminen ja 
tiukempi kustannustoimitus olisi voinut karsia turhaa toistoa kirjan alkupuolelta.

Marxilaiselle perinteelle ominaisesti Moore myös kritisoi voimakkaimmin itselleen läheisimpiä kirjoittajia. Esimerkiksi John Bellamy Fosterin "metabolisen repeämän" teorian kritisoiminen arvoteorian ja historiallisen metodin yhdistämisen puutteesta tuntuisi osuvan maaliin, mutta sen sijaan ruotsalaisen ympäristöhistorioitsijan Andreas Malmin viime aikaisten tutkimusten syyttäminen "fossilifetisistisiksi" ampuu ohi. Malm esittää kirjassaan Fossil Capital laajaan alkuperäisaineistoon nojaten, että höyrykonetta ei otettu käyttöön englantilaisessa puuvillateollisuudessa 1800-luvun alussa siksi, että se olisi ollut edullisempi tai tehokkaampi kuin päästötön vesivoima, vaan siksi, että höyrykoneen avulla työvoimaa oli helpompi kontrolloida tehtaissa ja kaupungeissa (Malm 2016). Tällainen tutkimus on kapitalismin historian ympäristöhistoriaa par excellence: hiili on hiiltä, ja vain tiettyjen yhteiskunnallisten olosuhteiden alaisuudessa siitä tulee fossiilista polttoainetta. Teollisten kasvihuonepäästöjen historiallinen kehitys on alusta alkaen poliittisen vallan ja pääoman kasautumisen historiaa. Mooren olisikin ehkä hyvä muistaa, että tutkimuksen temaattiselle ja ajalliselle rajaukselle - Malm esimerkiksi tarkastelee fossiilienergian merkitystä 1800-luvun alun Englannissa - on usein paikkansa. Pätevinkään historiallinen sosiologi ei voi tehdä kaikkea yhdellä kertaa.

Yhtä kaikki, Capitalism in the Web of Life on merkittävä teos ekologisen poliittisen taloustieteen saralla. Se on ohittamaton keskustelunavaus kaikille niille, jotka haluavat ymmärtää, kuinka olemme ylipäätänsä päätyneet nyt kohtaamaamme ekologiseen ja sosiaaliseen sekasotkuun.

\section{Viitteet}

I) Pitkän 1500-luvun (the long sixteenth century) ajatus juontuu Fernand Braudelilta, mutta sitä on käytetty erityisesti maailmanjärjestelmäanalyysissa kuvaamaan aikaväliä, jolloin luotiin eurooppalaisten dominoima kapitalistinen maailmantalous. Ks. Wallerstein (1974). 
2) Antroposeenilla tarkoitetaan historiallista aikakautta, jolloin ihmiskunnasta on kehittynyt maapallon ekosysteemejä pysyvästi muuttanut geologinen voima. Yhteiskuntatieteissä käsitettä on kritisoitu esimerkiksi siitä, että se on sokea historiallisille poliittis-taloudellisille valtasuhteille. Antroposeenin ajoittamisesta käydään myös vilkasta keskustelua, vaikkakin valtavirtainen käsitys pitää teollista vallankumousta ja höyrykonetta aikakauden alkuna. Ks. esim. Steffen ym. (2007), kritiikistä esim. Malm ja Hornborg (2014).

\section{Lähteet}

Malm, Andreas ja Hornborg, Alf. 2014. The geology of mankind? A critique of the Anthropocene narrative. The Anthropocene Review, 1:1, 62-69.

Malm, Andreas. 2016. Fossil Capital. The Rise of the Steam Power and Roots of the Global Warming. Lontoo: Verso.

Steffen, Will, Crutzen, Paul J. ja McNeill, John R. 2007. The Anthropocene: Are Humans Now Overwhelming the Great Forces of Nature. AMBIO: A Journal of the Human Environment, 36: 8, 614-621.

Wallerstein, Immanuel. 1974. The Modern World-system I. Capitalist Agriculture and the Origins of the European World-economy in the Sixteenth Century. Berkeley: University of California Press. 